\title{
Fluorescent Antibody Technique For Detection Of Salmonella Typhimurium In The Intestine Of Experimentally Infected Calves
}

\author{
Faisal, G. Habasha and Abdul Wahab Abul Razak \\ Dept. of Internal and preventive Vet. Med., College of Vet. Med., Baghdad \\ University, IRAQ
}

\begin{abstract}
Summary
A systemic study on the pathogenesis of experimentally induced Salmonella typhimurium infection was carried out in calves. Sixteen normal, colostrum-fed, friesian calves, ranging in age from 3 to 6 weeks were used. The calves were divided into two equal groups. Group I calves were inoculated orally with $1.5 \times 10^{11} \mathrm{CFU}$ of Salmonella typhimurium and group II calves served as control.

Using an indirect fluorescent antibody technique, it was found that Salmonella typhimurium has an apparent predilection for the small intestine particularly jejunum and ileum. The results of this study suggest that this technique can be considered as a rapid reliable technique for diagnosis of salmonellosis in endemic outbreaks.
\end{abstract}




\title{
التحري عن جراثيم سالمونيلا-الجرذان باختبار التالق المناعي غير المباشر في امعاء العجول المخمجه تجريبيا
}

\author{
فيصل غازي حباشه و عبد الوهاب عبد الرزلق \\ فرع الطب الباطني والوقائي البيطري-كلية الطب البيطري -جامعة بغداد- العراق
}

\section{الخلاصة}

صممت هذه الدراسـة لغرض معرفة جوانب امراضية جراثيم سـالمونيلا-الجرذان في العجول المخمجه

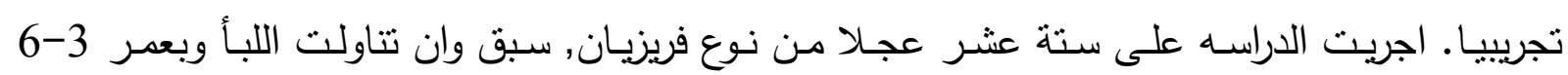
اسابيع. قسمت العجول الى مجموعتين , اعطيث المجموعه الاولى جرعه من الجراثيم مقدارها 1.5×11 بينما تركت المجموعه الثانيه كسيطره.

اظهرت نتـائج الفحص باختبـار التـالق المنـاعي غير المباشـر ميـل جـراثيم سـالمونيلا-الجـرذان للتمركز في منطقة الامعاء الاقيقه وخصوصا في الصائم واللفائفي حيث يمكن استعمال هذا الاختبار في تشخيص الثورات المرضية للمرض نظرا لكونه اختبار سربع.

\section{Introduction}

Presence of salmonella in food and feeds represents an important health hazard for man and other animals. Because of this hazard, many methods have been developed to detect, isolate and identify salmonella. It is beyond the scope of this paper to discus methods in detail. The methods have been reviewed extensively and well by others $(1,2,3)$. One of the methods of detection of these organisms is the fluorescent antibody technique ( FAT ) which was first described by ( $4 \& 5$ ).

In 1950 (6) developed a new dye (fluorescent isothiocyanate) "FITC" to label antibody globulin and thus paved the way for the modern development of the fluorescent antibody technique.

The reason for conducting this experiment was Totetsu the value of FAT to detect and localize Salmonella typhimurium in the intestine of experimentally infected calves. 


\section{Materials and Methods}

Experimental design:

Salmonella typhimurium strain used was a virulent and a drug resistant strain. It had been isolated from the faces of a calf at "Al-Dahab Al-Abyad" village that had died from an acute enteric disease (septicemic lesion with sever enteritis. This isolated strain has been used to reproduce the disease had typical salmonella reactions (morphology, biochemically and serologically.

Preparation of the bacterial inoculum was prepared by (7). Colonies of Salmonella typhimurium were picked from nutrient agar slant, inoculated in trypticase soy broth and inoculated at $37^{\circ} \mathrm{C}$ for 18 hours.

Each experimental calf was dosed orally ( after fasting for 36-48 hours and water deprived for 24 hours ) with $50 \mathrm{ml}$ trypticase soy broth in which the number of viable organisms in the inoculate was $1.5 \times 10$ ( CFU ). Calves served as control were given $50 \mathrm{ml}$ of sterile trypticase soy broth orally. Four millimeters thick sections were cut from frozen segments of duodenum, jejunum, ileum and mesenteric lymph nodes. Tissues were imbedded in $2.5 \%$ Methyl Cellulose, frozen and $6 \mu \mathrm{ml}$ thick sections were cut in a cryostatequipped microtome at $-28^{\circ} \mathrm{C}$. The sections were mounted on a glass slide, air dried and fixed in ethanol $95 \%$ and covered with rabbit anti-salmonella serum ( 1in 20 dilution ) which has been prepared as described by ( 8 ). The slides were held in moist chamber for 20 minutes. The slides were then washed for 15 minutes with three changes of $0.01 \mathrm{M}$ phosphate- buffered saline solution (PBSS), pH 7.2. The sections were treated with bovine anti-rabbit globulin $\mathrm{RAB} / \mathrm{FITC}$ ) for 20 minutes, mounted under a cover slip with glycerol and examined immediately by fluorescent microscope (Zeiss UV microscope).

\section{Results}

The localization of Salmonella typhimurium in different segments of the small and large intestine in summarized in table (1).

As early as 8 hours post-inoculation (PI), positive specific immunofluorescence result $(+++)$ were seen in the lumen of jejunum and ileum, while a moderate fluorescence $(++)$ was seen in the lumen of duodenum. Less fluorescence $(+)$ was observed in the mucosa of the jejunum and ileum (Fig.1), but no fluorescence was seen in the mucosa of the duodenum or colon. No fluorescence was seen in the lamina propria or sub mucosa of the small and large intestine. Little amount of fluorescent salmonella observed in the cortex and medulla of the mesenteric lymph nodes, particularly of the small intestine.

At 16 and 24 hours (PI), moderate numbers of fluorescing salmonella were seen in the lumen of duodenum, jejunum, ileum and colon, while only few 
fluorescent salmonella have been observed in the mucosal surface and lamina propria of jejunum and ileum, in addition to mucosa of duodenum and colon. Moderate numbers of fluorescing salmonella were also seen in the mesenteric lymph nodes.

At 36 hours (PI), only few salmonella were seen randomly distributed in sloughed cells present in the lumen of small and large intestine. The fluorescing salmonella were observed consistently in the intestinal epithelial surface and lamina properia of the small and large intestine. Fewer numbers were observed in the cortex and medulla of the mesenteric lymph nodes (Fig.2).

The localization of Salmonella typhimurium at 48 hours was demonstrated in the mucosa of lamina properia and submucosa of the small and large intestine. However Salmonella typhimurium was demonstrated only in the lumen of colon. Fluorescing salmonella were equally distributed in the cortex and medulla of the mesenteric lymph nodes.

At 72 hours (PI) Salmonella typhimurium was not seen in the duodenum, jejunum and ileum, similary the fluorescing salmonella were consistently demonstrated in the jejunum, colon and mesenteric lymph nodes.

The fluorescing salmonella were not detected in the different segments of the small and large intestine.

Fig. (1): Ileum of the calf sacrificed 8 hours (PI), showing salmonella in the cortex. 


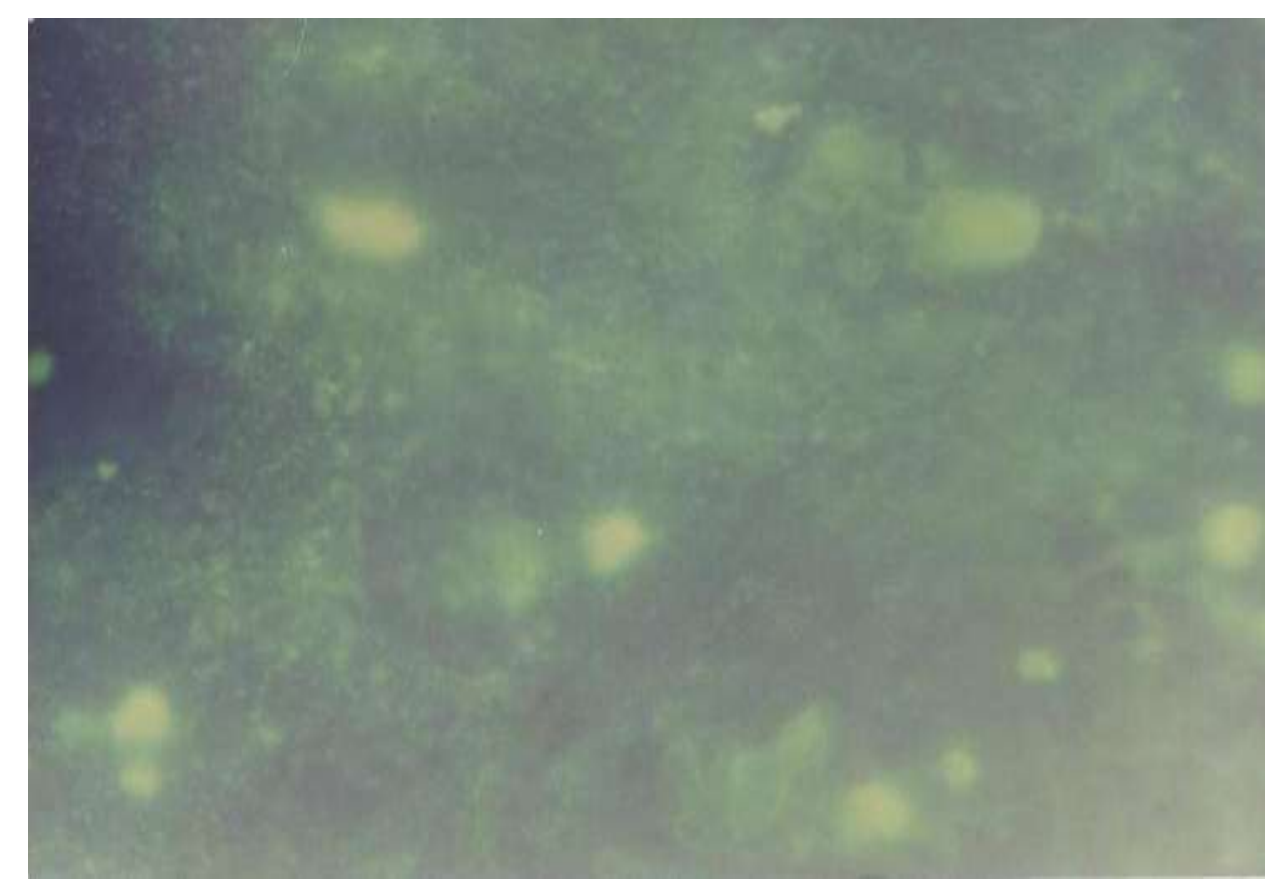

Fig. (2): The mesenteric lymph node of the calve sacrificed 36 hours (PI), showing salmonella in the cortex. 
Iraqi Journal of Veterinary Medicine Vol. 32, No. 2, 2008

Table (1): Localization of S.typhimurium in the intestine of experimental calves by fluorescent antibody examination.

\begin{tabular}{|c|c|c|c|c|c|c|c|c|c|}
\hline \multirow{3}{*}{$\begin{array}{l}\text { Calf } \\
\text { No. }\end{array}$} & \multirow{3}{*}{\begin{tabular}{|l|} 
Hours \\
after \\
inoculation \\
\end{tabular}} & \multirow{2}{*}{\multicolumn{4}{|c|}{ Duodenum }} & \multirow{2}{*}{\multicolumn{4}{|c|}{ Jejunum }} \\
\hline & & & & & & & & & \\
\hline & & Lumen & Mucosa & $\begin{array}{l}\text { Lamina } \\
\text { properia }\end{array}$ & Submucosa & Lumen & Mucosa & $\begin{array}{l}\text { Lamina } \\
\text { properia }\end{array}$ & Submucosa \\
\hline 412 & 8 & ++ & $-\mathrm{X}$ & - & - & $+++\mathrm{XXXX}$ & + & - & - \\
\hline $89 \mathrm{~A}$ & 16 & $++\mathrm{XXX}$ & $+\mathrm{xx}$ & - & - & ++ & + & + & - \\
\hline $81 \mathrm{~A}$ & 24 & ++ & + & - & - & ++ & + & + & - \\
\hline $51 \mathrm{~A}$ & 36 & + & + & + & - & + & + & + & - \\
\hline 55 & 48 & - & ++ & ++ & + & - & ++ & ++ & + \\
\hline 16 & 72 & - & - & - & - & - & - & - & - \\
\hline 15 & 98 & - & - & - & - & + & + & + & + \\
\hline 18 & 120 & - & - & - & - & + & + & + & + \\
\hline \multirow{2}{*}{$\begin{array}{l}\text { Calf } \\
\text { No. }\end{array}$} & \multirow{2}{*}{\begin{tabular}{|l|} 
Hours \\
after \\
inoculation
\end{tabular}} & \multicolumn{4}{|c|}{ Duodenum } & \multicolumn{4}{|l|}{ Jejunum } \\
\hline & & \begin{tabular}{|l|} 
Lumen \\
\end{tabular} & Mucosa & $\begin{array}{l}\text { Lamina } \\
\text { properia }\end{array}$ & Submucosa & Lumen & Mucosa & $\begin{array}{l}\text { Lamina } \\
\text { properia }\end{array}$ & Submucosa \\
\hline 412 & 8 & $++\mathrm{X}$ & + & - & - & - & - & - & - \\
\hline $89 \mathrm{~A}$ & 16 & $++\mathrm{XXX}$ & $+\mathrm{XX}$ & - & - & ++ & + & - & - \\
\hline $81 \mathrm{~A}$ & 24 & ++ & + & - & - & ++ & + & - & - \\
\hline $51 \mathrm{~A}$ & 36 & + & ++ & + & - & + & + & - & - \\
\hline 55 & 48 & - & - & ++ & + & - & ++ & + & + \\
\hline 16 & 72 & - & - & - & - & - & - & - & - \\
\hline 15 & 98 & - & - & - & - & + & + & + & + \\
\hline 18 & 120 & - & - & - & - & + & + & + & + \\
\hline
\end{tabular}


Iraqi Journal of Veterinary Medicine Vol. 32, No. 2, 2008

\begin{tabular}{|l|l|l|}
\hline Calf No. & $\begin{array}{l}\text { Hours after } \\
\text { inocutation }\end{array}$ & $\begin{array}{l}\text { Mesentric } \\
\text { lymph nodes }\end{array}$ \\
\hline 412 & 8 & + \\
\hline $89 \mathrm{~A}$ & 16 & ++ \\
\hline $81 \mathrm{~A}$ & 24 & ++ \\
\hline $51 \mathrm{~A}$ & 36 & + \\
\hline 55 & 48 & ++ \\
\hline 16 & 72 & ++ \\
\hline 15 & 98 & ++ \\
\hline 18 & 120 & ++ \\
\hline
\end{tabular}

$\mathrm{X}=$ No fluorescent bacteria

$\mathrm{XX}=$ Few fluorescent bacteria

$\mathrm{XXX}=$ Moderate number of fluorescent bacteria

$\mathrm{XXXX}=$ Many fluorescent bacteria 


\section{Discussion}

The results of ( IFAT ) in present study demonstrated that Salmonella typhimurium has an apparent predilection for the small intestine particularly jejunum and ileum. These finding were in agreement with similar predilection sites reported for the salmonella organism in mice ( 9 ), guinea pigs ( 10 ), chicken ( 11 ), weanling pigs ( 12 ), and rabbits ( 13 ). Preferable predilection site was probably duo to the presence of specific receptors on the jejunum and ileum which enhances the bacterial attachment, or could be the consequence of peristaltic movement and flushing of the organism to this location (14).

These finding were generally in agreement with the data provided and cultural examination of Salmonella typhimurum in the various parts of the small intestine and colon as in the mesenteric lymph nodes, indicates that the host defense mechanism was not efficient in preventing salmonella from invading the mucosa and reaching the local lymphoid tissue (peyer's patches) and mesenteric lymph nodes. Evidently the organism can colonize the peyre's patches of small intestine and invade the draining mesenteric lymph nodes, because it can resist phagocytosis by phagocytic cell (16 \& 17$)$.

Accordingly, our finding may suggest that this technique can be used as rapid and reliable technique for diagnosis of salmonellosis in endemic outbreaks.

\section{References}

1- Galton, M-M.; Morris, G.K. ; Martin, W.T. ( 1968 ) "Salmonella in foods and feeds". Cent. Dis. Control, Atlanta, Georgia.

2- Poelma, P. L. and Silliker, J. H. (1967) "In compendium of methods for the microbiological examination of foods". Am. Public health Associ. Washington D. C.: 301-310.

3- Silliker, J.H. and Greenberg, R.A. (1969) "In food - Born infections and Intoxications". ( Reimann, H.,ed. ) Academic press, New York, : 467-473.

4- Coons, A.; Greech, A. and Jones, R. (1941) "Immunological properties of an antibody containing a fluorescent group". Proc. Sec. Exp. Biol. Med. 47: 200202.

5- Coons, A.; Greech, A. and Jones, R. and Berliner, M. (1947). "The demonstration of pneumococcal antigen in tissue by the use of fluorescent antibody" .J.Immun.45.159- 170.

6- Coons, A. and Kaplan,M. (1950)"'Improvments in a methods for the detection of antigen by means of fluorescent antibody". J. Exp. Med. 91: 1-13.

7- Smith, B. P.; Habasha, F. G.; Reina-Guerra, M. (1980)"Immunization of calves against Salmonellosis". Am. J. Vet. Rec. 41: 1947-1951. 
8- Irene, K. and Hsu, H. (1983) "Histopathological study of protective immunity against murine Salmonellosis induced by killed vaccine”. Infec. Immun. 39 : 423-430.

9- Carter, P. and Collins, S.M. (1974) "The rate of the enteric infection in normal mice".J.Exp.Med. 131: 1189-1203.

10- Takeuchi, A. (1967) "Electron microscope studies of salmonella infection. IPenetration into the intestinal epithelium by Salmonella typhimurium".Am. J. Path. 501: 109-136.

11- Turnbull, P. and Snocyenbos, G. (1974). "Experimental salmonellosis in chicken.I-Fate and lost response in alimentary canal, liver and spleen. Avian Dis. $18: 153-177$.

12- Willie, C.; Olander, H. and Thacker, H. (1986). "Studies on the pathogenesis and Salmonella typhimurium and Salmonella cholerasuis Var Kunzendrof infection in weanling pigs". Am. J.Vet. Rec. 47: 76-83.

13- Wallis, T.; Starkey, W.; W.; Stephan, J. Haddon, S.; Osbome, M. and Candy, D. ( 1986 ). "The nature and role of mucosal damage in relation to Salmonella typhimurium induced fluid secretion in the rabbit ileum". J.Med.Microbio.22 :39-49

14- Willie, C.; Harvey, J. and Lean, H. (1985). "Studies on the pathogenisis of Salmonella heidelberg infection in weanling pigs". Am. J. Vet. Rec. 46: 23002310.

15- Yass, A.W.; Habasha, F.G. and Al-Darrji A.M. (1992)."The distribution of Salmonella typhimurium in fedal and cultures of experimentally-infected calves". Under publication.

16- Blanden,R.; Mackaness, G. and Collins, F. ( 1966 ). "Mechanisms of acquired resistance in mouse typhoid". J. Exp. Med. 124: 385-600.

17- Collins, F. (1970). "Immunity of enteric infection in mice". Infect. Immun. 1: 243-250. 